\title{
GMR
}

\section{Genetic divergence in the common bean (Phaseolus vulgaris L.) in the Cerrado-Pantanal ecotone}

\author{
F.A. da Silva ${ }^{1}$, A.M. Corrêa ${ }^{2}$, P.E. Teodoro ${ }^{3}$, K.V. Lopes $^{2}$ and C.C.G. Corrêa ${ }^{1}$ \\ ${ }^{1}$ Laboratório de Melhoramento Genético Vegetal, \\ Universidade Estadual do Norte Fluminense Darcy Ribeiro, \\ Campos dos Goytacazes, RJ, Brasil \\ ${ }^{2}$ Departamento de Fitotecnia, \\ Universidade Estadual do Mato Grosso do Sul, Aquidauana, MS, Brasil \\ ${ }^{3}$ Departamento de Agronomia, \\ Universidade Federal do Mato Grosso do Sul, Chapadão do Sul, MS, Brasil \\ Corresponding author: F.A. da Silva \\ E-mail: flavia_uems@hotmail.com \\ Genet. Mol. Res. 16 (1): gmr16019570 \\ Received December 9, 2016 \\ Accepted February 8, 2017 \\ Published March 30, 2017 \\ DOI http://dx.doi.org/10.4238/gmr16019570
}

Copyright (C) 2017 The Authors. This is an open-access article distributed under the terms of the Creative Commons Attribution ShareAlike (CC BY-SA) 4.0 License.

\begin{abstract}
Evaluating genetic diversity among genotypes is important for providing parameters for the identification of superior genotypes, because the choice of parents that form segregating populations is crucial. Our objectives were to i) evaluate agronomic performance; ii) compare clustering methods; iii) ascertain the relative contributions of the variables evaluated; and iv) identify the most promising hybrids to produce superior segregating populations. The trial was conducted in 2015 at the State University of Mato Grosso do Sul, Brazil. We used a randomized block design with three replications, and recorded the days to emergence, days to flowering, days to maturity, plant height, number of branches, number of pods, number of seeds per pod, weight of 100 grains, and productivity. The genetic diversity of the genotypes was determined by cluster analysis using two dissimilarity measures: the
\end{abstract}

Genetics and Molecular Research 16 (1): gmr16019570 
Euclidean distance and the standardized mean Mahalanobis distance using the Ward hierarchical method. The genotypes 'CNFC 10762', 'IAC Dawn', and 'BRS Style' had the highest grain yields, and clusters that were based on the Euclidean distance differed from those based on the Mahalanobis distance, the second being more precise. The yield grain character has greater relevance to the dispute. Hybrids with a high heterotic effect can be obtained by crossing 'IAC Alvorada' with 'CNFC 10762', 'IAC Alvorada' with 'CNFC 10764', and 'BRS Style' with 'IAC Alvorada'.

Key words: Phaseolus vulgaris; Grain yield; Euclidean distance; Mahalanobis distance

\section{INTRODUCTION}

In Brazil, the common bean (Phaseolus vulgaris L.) is grown almost nationwide and throughout the year. The crop has great economic and social importance, and annually covers an area of about three million hectares that produces between three and three-and-ahalf million tons of grain, with an average yield that is slightly higher than $1000 \mathrm{~kg} / \mathrm{ha}$. In 2014-2015 in the State of Mato Grosso do Sul, an area of 17,100 ha produced 27,600 tons of grain, with an average yield of $1814 \mathrm{~kg} / \mathrm{ha}(\mathrm{CONAB}, 2015)$. However, in the CerradoPantanal ecotone, little information has been obtained on cultivar performance (Santos et al., 2011; Correa et al., 2015).

Several research institutions in Brazil have developed genetic breeding programs to maintain the national average grain yield of the crop at low levels. The crop is highly susceptible to biotic and abiotic stressors, its architecture is inappropriate for mechanical harvesting, and its productivity and grain quality need improving (Zimmermann et al., 1996). When starting a genetic breeding program, one of the most crucial aspects is the choice of parents (Correa and Gonçalves, 2012). Genetic divergence between individuals or populations is important in breeding programs that involve hybridization, because it facilitates the identification of parents that produce heterotic progeny and results in a higher probability of obtaining superior genotypes in segregating generations (Vidigal et al., 1997; Bertan et al., 2003; Benitez et al., 2011).

Falconer (1981) stated that in genetic breeding programs, genetic dissimilarity, i.e., differences in allele frequencies, is fundamentally important in choosing genotypes to be used as parents, because the genetic divergence between parents is indicative of heterotic expression in progenies. Falconer and Mackay (1996) stated that hybrid heterosis is caused by dominance effects of the trait involved and the square of the difference in allele frequencies with their parents, in addition to the epistatic effects that are usually neglected. Genetic divergence in the common bean has been estimated by Coelho et al. (2007), Correa and Gonçalves (2012), and Gonçalves et al. (2014).

Choosing parents by analyzing their behavior and the results of diallel crosses present practical difficulties when many parents are involved. Predictive measures, such as the Euclidean distance (D) and Mahalanobis distance $\left(\mathrm{D}^{2}\right)$, are based on morphological and physiological differences of the parents, and have the advantage of not requiring a priori hybrid combinations, which encourages breeders to focus their efforts on more contrasting combinations (Cruz et al., 2014).

Genetics and Molecular Research 16 (1): gmr16019570 
Recently, multivariate analysis has been used to estimate genetic divergence, because it reduces the number of variables required and simplifies the process of obtaining the genetic distance. Multivariate analysis can identify groups of similar individuals after the estimation of a similarity matrix, such that there is homogeneity within and heterogeneity between the groups.

This study aimed to evaluate the agronomic performances of 17 common bean genotypes grown in the Cerrado-Pantanal ecotone, to cluster common bean genotypes based on their genetic divergence, to ascertain the relative contributions of the traits evaluated to genetic divergence, and to identify the most promising hybrid combinations for producing superior segregating populations.

\section{MATERIAL AND METHODS}

The trial was conducted in April and June 2015 at the Universidade Estadual de Mato Grosso do Sul, Unit of Aquidauana ( $20^{\circ} 27^{\prime} 0^{\prime \prime} \mathrm{S}, 55^{\circ} 48^{\prime} 0^{\prime \prime} \mathrm{W} ; 170 \mathrm{~m}$ above mean sea level). The region's climate, according to the Köppen-Geiger classification, is Aw (Savana Tropical), with an average annual rainfall of $1200 \mathrm{~mm}$ and an average annual temperature of $24^{\circ} \mathrm{C}$, with a maximum daily temperature of $36^{\circ} \mathrm{C}$ during the spring and a minimum of $12^{\circ} \mathrm{C}$ in winter, and frosts are rare. The soil of the area has been categorized by Schiavo et al. (2010), following the criteria of EMBRAPA (2006), as Ultisol dystrophic, and has a sandy texture, is moderately deep and well-drained, and according to a soil chemical analysis (Table 1), fertile.

Table 1. Soil chemical analysis from experimental unit of the Universidade Estadual do Mato Grosso do Sul, sector Fitotecnia, Aquidauana, MS.

\begin{tabular}{|c|c|c|c|c|c|c|c|c|c|}
\hline Layer & $\mathrm{pH}$ & $\mathrm{Al}$ & $\mathrm{Ca}+\mathrm{Mg}$ & $\mathrm{K}$ & $P$ & O.M. & $\mathrm{V}$ & $\mathrm{m}$ & CEC \\
\hline $\mathrm{Cm}$ & $\mathrm{H}_{2} \mathrm{O}$ & & $\mathrm{mol} / \mathrm{dm}^{3}$ & & $\mathrm{mg} / \mathrm{dm}^{3}$ & $\mathrm{~g} / \mathrm{dm}^{3}$ & & & $\mathrm{cmol}_{\mathrm{c} / \mathrm{dm}^{3}}$ \\
\hline $0-20$ & 6.2 & 0.0 & 4.31 & 0.2 & 41.3 & 19.74 & 45 & 0 & 5.1 \\
\hline
\end{tabular}

The genotypes used were obtained from the germplasm bank of the Embrapa Arroz e Feijão (EMBRAPA-CNPAF) and consisted of cultivars and advanced lines that are described in Table 2. The trial was conducted with a randomized block design, with three replications. Each experimental unit consisted of four 4.0-m-long rows of plants that were spaced $0.5 \mathrm{~m}$ apart, being considered as useful area the two central rows of each unit. The soil was prepared under the conventional tillage system, and, subsequently, it was performed the mechanical opening of the grooves, which were fertilized at $300 \mathrm{~kg} \mathrm{ha}^{-1}$ using chemical fertilizers with the commercial formula 4-20-20. Sowing was performed manually on April 27, 2015 at a density of 15 seed $\mathrm{m}^{-1}$, and cultivation was conducted following the recommendations of EMBRAPA (2012). The harvest was performed on July 30 and 31, 2015.

The following traits were evaluated: i) days of emergence (DE), the number of days between sowing and the day in which $50 \%$ of the seedlings in each plot had emerged (stage V1); ii) days of flowering (DF), the number of days in which $50 \%$ of the seedlings in each plot were at stage V1 and 50\% of the plants had at least one flower open (stage R6); iii) days of maturation (DM), the number of days in which $50 \%$ of the plants in each plot were at the V1 stage and $50 \%$ of the plants had at least one pod with modified coloration (stage R9); iv) the plant height $(\mathrm{PH})$ of eight randomly selected plants in the useful area of each plot was measured at harvest with a graduated centimeter ruler, and was the distance between the ground and the apex of the main stem; v) the number of ramifications (NR, the number

Genetics and Molecular Research 16 (1): gmr16019570 
Table 2. Genetic class, commercial group and gene pool of 17 common bean genotypes grown in Cerrado/ Pantanal ecotone. Aquidauana, MS, 2015.

\begin{tabular}{l|l|l|l}
\hline Genotype & Genetic class & Commercial group & Gene pool \\
\hline BRS Campeiro & Cultivar & Black & Mesoamerican \\
\hline CNFP 10794 & Line & Carioca & Mesoamerican \\
\hline BRSMG Madrepérola & Cultivar & Black & Mesoamerican \\
\hline IAC Alvorada & Cultivar & Carioca & Mesoamerican \\
\hline BRS Estilo & Cultivar & Carioca & Mesoamerican \\
\hline CNFC 10429 & Line & Carioca & Mesoamerican \\
\hline CNFC 10729 & Line & Carioca & Mesoamerican \\
\hline BRS Ametista & Cultivar & Carioca & Mesoamerican \\
\hline BRS Notável & Cultivar & Carioca & Mesoamerican \\
\hline TAA Bola cheia & Cultivar & Carioca & Mesoamerican \\
\hline IAPAR 81 & Cultivar & Carioca & Mesoamerican \\
\hline IPR Tangará & Cultivar & Carioca & Mesoamerican \\
\hline CNFC 10762 & Line & Carioca & Mesoamerican \\
\hline BRS Esteio & Cultivar & Black & Mesoamerican \\
\hline BRS Esplendor & Cultivar & Black & Mesoamerican \\
\hline IAC Diplomata & Cultivar & Black & Mesoamerican \\
\hline Pérola & Cultivar & Carioca & Mesoamerican \\
\hline
\end{tabular}

of secondary branches derived from the main stem) on eight randomly selected plants in the useful area of each plot at harvest; vi) the number of pods per plant (NPP) of eight randomly selected plants in the useful area of each plot at harvest; vii) the number of grains per pod (NGV) on five randomly selected pods taken from each plant that was used for the evaluation of NPP (40 pods per plot); viii) the weight of 100 grains (WHG) in the useful area of each plot was measured using a semi-analytical balance with an accuracy of two decimal places, and moisture was adjusted to $13 \%$; and ix) grain yield (YIE) in the useful area of each plot (kg/ha), adjusted for $13 \%$ moisture.

The data obtained were initially subjected to the Shapiro-Wilk test $(\mathrm{P}<0.05)$ to check the normality and Bartlett's test to check the homogeneity of variances. The degree of multicollinearity of the matrix X X' was established based on its number of conditions (NC), which is the ratio between the highest and the lowest matrix eigenvalues (Montgomery and Peck, 1981). If $\mathrm{NC}<100$, multicollinearity is weak and not a problem; if $\mathrm{NC}$ is between 100 and 1000 , multicollinearity is considered moderate to strong; and if $\mathrm{NC}>1000$, multicollinearity is determined as severe.

We conducted an analysis of variance with genotype and block effects as fixed terms and the errors as random terms, adopting the statistical model below (Cruz et al., 2014):

$$
Y_{i j}=\mu+g_{i}+b_{j}+\varepsilon_{j}
$$

(Equation 1)

where $Y_{i j}$ is the observed value of the $i$ th genotype in the $j$ th block, $\mu$ is the overall mean for the trial, $g_{i}$ is the effect of the $i$ th genotype $(i=1,2, \ldots, \mathrm{g}), b_{j}$ is the effect of the $j$ th block $(j=1$, $2, \ldots, \mathrm{r})$, and $\varepsilon_{i j}$ is the random error associated with observation $Y_{i j}$.

Average values of the traits evaluated were clustered by the Scott-Knott method (Scott and Knott, 1974) at the 5\% probability level. The Scott-Knott test distinguishes between subsets of genotypes that differ significantly, and is extremely useful to breeders.

Prior to conducting multivariate analysis, the data were standardized, because different measurement scales were used. The original average $X_{i j}$, which was obtained for descriptor $j$ in genotype $i$, was divided by the standard deviation $(S j)$ of the corresponding descriptor $j$, which generated a reduced-average $Z_{i j}$ with unitary variance:

Genetics and Molecular Research 16 (1): gmr16019570 


$$
Z_{i j}=\frac{X_{i j}}{S j}
$$

(Equation 2)

Genetic divergence between the genotypes was determined by cluster analysis using two dissimilarity measurements, the Euclidean distance (D):

$$
d_{i i^{\prime}}=\sqrt{\frac{1}{n} \sum\left(X_{i j}-X_{i^{\prime} j}\right)^{2}}
$$

where is the distance between genotypes $i$ and $i$ ', is the observation in the $i$ th parent for the $j$ th trait, and $n$ is the number of traits under study; and the Mahalanobis generalized distance $\left(\mathrm{D}^{2}\right)$, which was obtained in the following manner:

$$
D_{i i^{\prime}}^{2}=\delta^{\prime} \psi^{-1} \psi
$$

where $D_{\ddot{u}}^{2}$, is the Mahalanobis distance between genotypes $i$ and $i$, and $\psi$ is the residual variance and covariance matrix; and

$$
\delta^{\prime}=\left[d_{1} d_{2} \ldots d_{v}\right], \text { being } \mathrm{d}_{\mathrm{j}}=Y_{i j}-Y_{i^{\prime} j^{\prime}}
$$

where $Y_{i j}$ is the measurement of the $i$ th genotype in relation to the $j$ th variable.

"We used the Ward (1963) hierarchical method to delimit the groups, and identified pairs of accessions that had a low sum of squares of deviations in the distances square matrix, $d^{2}$ (or sums of squares of the deviations matrix, $S S D_{i i}$ ). A dissimilarity matrix of lower dimensions was then calculated:

$$
S S D_{(i j k)}=\frac{1}{k} d_{(i j k)}^{2}
$$

where $K$ is the number of accessions in the group. These methods produce consistent patterns of genotype clustering (Teodoro et al., 2015).

The relative importance of each trait in terms of genetic dissimilarity was evaluated based on the $\mathrm{D}^{2}$ components for each trait and the total dissimilarity observed, using the criterion proposed by Singh (1981) that is based on statistic $S . j^{\prime}$ :

$$
D_{i i^{\prime}}^{2}=\delta^{\prime} \psi^{-1} \delta=\sum_{j=1}^{n} \sum_{j^{\prime}=1}^{n} \omega_{i j j^{\prime}} d_{j} d_{j^{\prime}}
$$

where $\omega_{j j}$, is the element of the $j$ th line and $j$ th inverse column of the residual variance and covariance matrix. All of the statistical analyses were performed using GENES software (Cruz, 2013), and followed the recommendations of Cruz et al. (2014).

Genetics and Molecular Research 16 (1): gmr16019570 


\section{RESULTS AND DISCUSSION}

For all traits, except NGP, there were significant differences $(\mathrm{P}<0.05)$ between the genotypes (Table 3), which indicates genetic variability in the population that is crucial for breeding programs. Lemos et al. (2004) and Teixeira et al. (2011), working with common bean populations, also reported a lack of variability in NGP, possibly because few genes control this trait and there is little or no influence of external factors, such as climatic conditions (Ribeiro et al., 2014).

Table 3. Summary of analysis of variance for the traits days for emergence (DE), plant height (PH), number of ramifications per plant (NR), days for flowering (DF), days for maturation (DM), number of pods per plant (NPP), number of grains per pod (NGP), weight of hundred grains (WHG) and grain yield (YIE) of 17 common bean genotypes grown in Cerrado/Pantanal ecotone.

\begin{tabular}{l|c|c|c|c|c|c|c|c|c}
\hline \multirow{2}{*}{ S.V. } & \multicolumn{9}{|c}{ Mean square } \\
\cline { 2 - 10 } & DE & PH & NR & DF & DM & NPP & NGP & WHG & YIE \\
\hline Genotypes & $0.24^{*}$ & $14.23^{*}$ & $40.82^{*}$ & $17.12^{*}$ & $1.99^{*}$ & $14.55^{*}$ & $0.97^{n s}$ & $22.65^{*}$ & $104.49^{*}$ \\
\hline C.V(\%) & 9.11 & 8.82 & 5.79 & 2.10 & 5.20 & 2.84 & 25.85 & 3.18 & 6.92 \\
\hline
\end{tabular}

$\mathrm{S} . \mathrm{V}=$ Sources of variation; ${ }^{*}{ }^{\mathrm{ns}}=$ significant and no significant at $5 \%$ by $\mathrm{F}$ test; respectively; $\mathrm{CV}=$ coefficient of variation.

The performances of genotypes that were partially damaged due to water stress at the phenological stages R7 and R8 are presented in Table 4. The average grain yield was $1121 \mathrm{~kg}$ $\mathrm{ha}^{-1}$, and ranged from $582 \mathrm{~kg} / \mathrm{ha}$ for 'BRS Esplendor', which did not significantly differ to that of 'Pérola' (617 kg/ha), to $1859 \mathrm{~kg} \mathrm{ha}^{-1}$ for 'CNFC 10762', which did not significantly differ to that of 'IAC Alvorada' (1836 kg/ha) or 'BRS Estilo' (1776 kg/ha), which had the highest grain yields.

Table 4. Mean values for the days for emergence (DE), plant height (PH), number of ramifications per plant (NR), days for flowering (DF), days for maturation (DM), number of pods per plant (NPP), number of grains per pod (NGP), weight of hundred grains (WHG) and grain yield (YIE) of 17 common bean genotypes grown in Cerrado/Pantanal ecotone.

\begin{tabular}{|c|c|c|c|c|c|c|c|c|c|c|}
\hline Genotype & Number & $\overline{\mathrm{DE}}$ & $\mathrm{PH}$ & NR & $\mathrm{DF}$ & DM & NPP & NGP & WHG & YIE \\
\hline BRS Ametista & 1 & $10.33^{\mathrm{a}}$ & $68.00^{\mathrm{c}}$ & $14.67^{\mathrm{c}}$ & $46.33^{\mathrm{d}}$ & $73.67^{\mathrm{a}}$ & $5.50^{\mathrm{c}}$ & $2.97^{\mathrm{a}}$ & $30.10^{\mathrm{d}}$ & $781.00^{\mathrm{e}}$ \\
\hline BRS Campeiro & 2 & $10.67^{\mathrm{a}}$ & $101.33^{\mathrm{a}}$ & $14.33^{\mathrm{c}}$ & $48.67^{\mathrm{c}}$ & $66.33^{\mathrm{b}}$ & $8.90^{\mathrm{b}}$ & $4.13^{\mathrm{a}}$ & $31.01^{\mathrm{c}}$ & $1259.00^{\mathrm{c}}$ \\
\hline BRS Esplendor & 3 & $9.00^{\mathrm{b}}$ & $59.33^{\mathrm{d}}$ & $20.00^{\mathrm{b}}$ & $48.00^{\mathrm{c}}$ & $67.67^{\mathrm{b}}$ & $4.00^{\mathrm{d}}$ & $4.00^{\mathrm{a}}$ & $23.33^{\mathrm{f}}$ & $582.00^{\mathrm{f}}$ \\
\hline BRS Esteio & 4 & $12.67^{\mathrm{a}}$ & $77.33^{\mathrm{b}}$ & $18.33^{\mathrm{b}}$ & $47.00^{\mathrm{d}}$ & $71.33^{\mathrm{a}}$ & $6.67^{\mathrm{c}}$ & $4.97^{\mathrm{a}}$ & $29.75^{\mathrm{d}}$ & $1672.00^{\mathrm{b}}$ \\
\hline BRS Estilo & 5 & $11.33^{\mathrm{a}}$ & $50.33^{\mathrm{e}}$ & $10.00^{\mathrm{d}}$ & $47.00^{\mathrm{d}}$ & $68.00^{\mathrm{b}}$ & $6.23^{\mathrm{c}}$ & $4.40^{\mathrm{a}}$ & $32.59^{\mathrm{b}}$ & $1776.00^{\mathrm{a}}$ \\
\hline BRS Notável & 6 & $10.67^{\mathrm{a}}$ & $55.33^{\mathrm{d}}$ & $17.67^{\mathrm{b}}$ & $48.00^{\mathrm{c}}$ & $66.33^{\mathrm{b}}$ & $4.63^{\mathrm{e}}$ & $3.93^{\mathrm{a}}$ & $29.05^{\mathrm{d}}$ & $753.00^{\mathrm{e}}$ \\
\hline BRSMG Madrepérola & 7 & $10.67^{\mathrm{a}}$ & $103.33^{\mathrm{a}}$ & $16.33^{\mathrm{c}}$ & $50.00^{\mathrm{b}}$ & $70.67^{\mathrm{a}}$ & $6.13^{\mathrm{c}}$ & $3.47^{\mathrm{a}}$ & $29.60^{\mathrm{d}}$ & $677.00^{\mathrm{e}}$ \\
\hline CNFC 10429 & 8 & $9.67^{\mathrm{a}}$ & $50.67^{\mathrm{e}}$ & $11.33^{\mathrm{d}}$ & $54.00^{\mathrm{a}}$ & $66.67^{\mathrm{b}}$ & $7.73^{b}$ & $4.10^{\mathrm{a}}$ & $27.95^{\mathrm{d}}$ & $719.00^{\mathrm{e}}$ \\
\hline CNFC 10729 & 9 & $12.33^{\mathrm{a}}$ & $79.00^{\mathrm{b}}$ & $18.67^{\mathrm{b}}$ & $49.00^{c}$ & $71.33^{\mathrm{a}}$ & $4.10^{\mathrm{d}}$ & $4.17^{\mathrm{a}}$ & $29.63^{d}$ & $724.00^{\mathrm{e}}$ \\
\hline CNFC 10762 & 10 & $11.00^{\mathrm{a}}$ & $78.00^{\mathrm{b}}$ & $15.00^{\mathrm{c}}$ & $54.00^{\mathrm{a}}$ & $63.00^{\mathrm{b}}$ & $8.33^{\mathrm{b}}$ & $5.40^{\mathrm{a}}$ & $32.11^{\mathrm{b}}$ & $1859.00^{\mathrm{a}}$ \\
\hline CNFP 10794 & 11 & $9.33^{\mathrm{b}}$ & $66.67^{c}$ & $12.00^{\mathrm{d}}$ & $54.67^{\mathrm{a}}$ & $65.33^{\mathrm{b}}$ & $10.47^{\mathrm{a}}$ & $5.43^{\mathrm{a}}$ & $30.74^{\mathrm{c}}$ & $1166.00^{\mathrm{c}}$ \\
\hline IAC Alvorada & 12 & $10.67^{\mathrm{a}}$ & $81.00^{\mathrm{b}}$ & $11.67^{\mathrm{d}}$ & $50.67^{\mathrm{b}}$ & $66.33^{\mathrm{b}}$ & $7.30^{\mathrm{b}}$ & $4.60^{\mathrm{a}}$ & $34.65^{\mathrm{a}}$ & $1836.00^{\mathrm{a}}$ \\
\hline IAC Diplomata & 13 & $10.33^{\mathrm{a}}$ & $86.00^{\mathrm{b}}$ & $27.33^{\mathrm{a}}$ & $51.00^{\mathrm{b}}$ & $66.67^{\mathrm{b}}$ & $5.97^{\mathrm{c}}$ & $4.43^{\mathrm{a}}$ & $29.44^{\mathrm{d}}$ & $986.00^{\mathrm{d}}$ \\
\hline IAPAR 81 & 14 & $9.00^{\mathrm{b}}$ & $75.33^{b}$ & $13.67^{\mathrm{c}}$ & $51.00^{\mathrm{b}}$ & $68.00^{\mathrm{b}}$ & $8.80^{\mathrm{b}}$ & $4.47^{\mathrm{a}}$ & $33.51^{\mathrm{a}}$ & $1544.00^{\mathrm{b}}$ \\
\hline IPR Tangará & 15 & $11.00^{\mathrm{a}}$ & $74.33^{\mathrm{b}}$ & $19.67^{\mathrm{b}}$ & $51.00^{\mathrm{b}}$ & $66.67^{\mathrm{b}}$ & $5.40^{\mathrm{c}}$ & $4.87^{\mathrm{a}}$ & $29.26^{\mathrm{d}}$ & $1173.00^{\mathrm{c}}$ \\
\hline Pérola & 16 & $10.33^{\mathrm{a}}$ & $73.33^{b}$ & $20.00^{\mathrm{b}}$ & $51.00^{\mathrm{b}}$ & $73.00^{\mathrm{a}}$ & $7.67^{\mathrm{b}}$ & $5.10^{\mathrm{a}}$ & $26.61^{\mathrm{e}}$ & $617.00^{\mathrm{f}}$ \\
\hline TAA Bola Cheia & 17 & $10.67^{\mathrm{a}}$ & $96.67^{\mathrm{a}}$ & $20.67^{\mathrm{b}}$ & $51.00^{\mathrm{b}}$ & $69.67^{\mathrm{a}}$ & $4.47^{\mathrm{b}}$ & $4.63^{\mathrm{a}}$ & $29.42^{\mathrm{d}}$ & $933.00^{\mathrm{d}}$ \\
\hline Mean & & 10.56 & 75.05 & 16.54 & 50.13 & 68.27 & 6.60 & 4.41 & 29.92 & 1121 \\
\hline
\end{tabular}

Averages followed by the same letters in the same column belong to the same group by Skott-Knott test.

Although the average grain yield obtained was higher than the national average $(1059 \mathrm{~kg} / \mathrm{ha}$; CONAB, 2015), it was well below that obtained in the State $(1814 \mathrm{~kg} / \mathrm{ha}$ in the 2014/2015 harvest).

Genetics and Molecular Research 16 (1): gmr16019570 
Precocity is a desirable feature, because it allows farmers to grow the crop for a shorter period, making it less susceptible to weather damage. On average, the genotypes were physiologically mature at 68 days. Harvesting depended on environmental conditions, and was conducted between 15 to 20 days after the crop had reached physiological maturity; on average, there were 83-88 days from emergence to harvest, which is normal (Araújo et al., 1996).

The most similar genotypes based on the Euclidean distance (D) were 'IPR Tangará' (15) and 'TAA Bola Cheia' (17) $(\mathrm{D}=0.58)$, whereas the most similar based on the Mahalanobis distance $\left(\mathrm{D}^{2}\right)$ were 'IAC Alvorada' $(12)$ and 'IAPAR 81' $(14)\left(\mathrm{D}^{2}=30.69\right)$ (Table 5). Similar genotypes are not recommended for use in genetic breeding programs by hybridization, because the genetic variability of segregating populations should not be restricted (Correa and Gonçalves, 2012); genetically similar parents tend to share many genes or alleles, and their crossing results in a low level of allelic heterozygosity (Cruz et al., 2014). The most divergent pair according to the Euclidian distance was 'Ametista' (1) and 'CNFC 10762' (10) (D = 2.00), while according to the Mahalanobis distance, it was 'BRS Esplendor' (3) and 'CNFC 10762 ' $(10)\left(\mathrm{D}^{2}=690.10\right)$. High divergence, in principle, maximizes heterosis in the progeny, and increases the probability of obtaining superior segregants in later generations because of different numbers of loci in which dominance effects are evident (Cruz et al., 2014).

Table 5. Genetic distance among 17 common bean genotypes grown in Cerrado-Pantanal ecotone based on Euclidian distance (upper diagonal) and Mahalanobis distance (lower diagonal).

\begin{tabular}{l|c|c|c|c|c|c|c|c|c|c|c|c|c|c|c|c|c}
\hline Genotype & 1 & 2 & 3 & 4 & 5 & 6 & 7 & 8 & 9 & 10 & 11 & 12 & 13 & 14 & 15 & 16 & 17 \\
\hline 1 & & 1.36 & 1.17 & 1.33 & 1.31 & 1.01 & 0.96 & 1.36 & 0.94 & 2.00 & 1.87 & 1.49 & 1.34 & 1.38 & 1.26 & 1.24 & 1.18 \\
\hline 2 & 166.86 & & 1.75 & 1.32 & 1.51 & 1.56 & 1.19 & 1.46 & 1.46 & 1.44 & 1.22 & 0.87 & 1.10 & 0.84 & 1.13 & 1.50 & 1.17 \\
\hline 3 & 119.32 & 414.04 & & 1.63 & 1.57 & 0.74 & 1.24 & 1.19 & 1.19 & 1.89 & 1.84 & 1.81 & 1.19 & 1.67 & 1.11 & 1.09 & 1.16 \\
\hline 4 & 187.99 & 474.04 & 359.57 & & 0.93 & 1.25 & 1.30 & 1.65 & 1.05 & 1.32 & 1.74 & 1.12 & 1.25 & 1.40 & 0.92 & 1.22 & 1.09 \\
\hline 5 & 249.24 & 298.99 & 450.85 & 58.20 & & 1.06 & 1.52 & 1.39 & 1.43 & 1.25 & 1.63 & 0.98 & 1.57 & 1.57 & 1.09 & 1.51 & 1.44 \\
\hline 6 & 40.91 & 293.64 & 66.02 & 186.68 & 233.00 & & 1.08 & 1.05 & 1.09 & 1.53 & 1.70 & 1.70 & 1.10 & 1.48 & 0.81 & 1.08 & 1.03 \\
\hline 7 & 215.40 & 132.80 & 456.80 & 381.77 & 567.90 & 313.95 & & 1.03 & 0.99 & 1.62 & 1.71 & 1.39 & 1.03 & 1.39 & 1.01 & 1.00 & 0.68 \\
\hline 8 & 97.58 & 272.47 & 160.10 & 270.96 & 260.31 & 82.91 & 350.49 & & 1.42 & 1.36 & 0.98 & 1.34 & 1.34 & 1.14 & 1.14 & 1.09 & 1.09 \\
\hline 9 & 97.58 & 193.91 & 103.36 & 208.68 & 299.83 & 47.31 & 230.08 & 104.39 & & 1.76 & 1.74 & 1.37 & 0.99 & 1.47 & 0.89 & 1.14 & 0.80 \\
\hline 10 & 412.02 & 236.51 & 690.10 & 113.20 & 127.96 & 409.82 & 451.63 & 379.31 & 426.05 & & 1.13 & 0.90 & 1.36 & 1.18 & 1.00 & 1.53 & 1.36 \\
\hline 11 & 163.96 & 138.94 & 369.32 & 184.19 & 167.56 & 199.87 & 342.46 & 80.52 & 182.07 & 180.28 & & 1.10 & 1.39 & 0.82 & 1.24 & 1.41 & 1.52 \\
\hline 12 & 321.34 & 147.30 & 654.00 & 105.26 & 101.13 & 378.70 & 420.37 & 349.83 & 347.28 & 44.92 & 136.91 & & 1.24 & 0.63 & 0.96 & 0.96 & 1.21 \\
\hline 13 & 104.63 & 206.72 & 171.94 & 128.99 & 246.85 & 84.32 & 283.86 & 181.98 & 70.66 & 289.19 & 188.08 & 266.82 & & 1.17 & 0.62 & 1.04 & 0.63 \\
\hline 14 & 198.98 & 109.57 & 476.21 & 95.06 & 90.87 & 254.26 & 366.87 & 216.21 & 232.98 & 92.41 & 58.01 & 30.69 & 173.37 & & 1.08 & 1.39 & 1.26 \\
\hline 15 & 85.81 & 176.78 & 173.98 & 95.06 & 130.16 & 62.82 & 284.32 & 110.87 & 65.68 & 188.62 & 110.16 & 173.90 & 32.03 & 108.41 & & 0.90 & 0.58 \\
\hline 16 & 52.93 & 213.98 & 103.93 & 221.62 & 332.97 & 62.82 & 171.63 & 86.96 & 59.08 & 403.97 & 181.69 & 396.56 & 96.69 & 267.72 & 89.37 & & 0.86 \\
\hline 17 & 103.86 & 109.98 & 246.01 & 169.33 & 318.29 & 136.22 & 87.95 & 203.05 & 76.84 & 276.09 & 200.19 & 251.31 & 71.98 & 196.15 & 73.83 & 81.03 & \\
\hline
\end{tabular}

1 - BRS Ametista, 2 - BRS Campeiro, 3 - BRS Esplendor, 4 - BRS Esteio, 5 - BRS Estilo, 6 - BRS Notável, 7 BRSMG Madrepérola, 8 - CNFC 10429, 9 - CNFC 10729, 10 - CNFC 10762, 11 - CNFP 10794, 12 - IAC Alvorada, 13 - IAC Diplomata, 14 - IAPAR 81, 15 - IPR Tangará, 16 - Pérola, 17 - TAA Bola Cheia.

According to Martins et al. (2002), only choosing parents based on their differences without considering their performances must be avoided, and crosses should be performed between parents that exhibit superior performance in terms of the crop's main agronomic traits. The cross between 'BRS Esplendor' (3) and 'CNFC 10762' $(10)\left(\mathrm{D}^{2}=690.10\right)$ could result in obtaining highly productive progeny, because 'CNFC 10762' (10) had the highest average grain yield; the same is true of the cross between 'Ametista' and 'CNFC 10762' (Table 5).

The cross between 'BRS Esplendor' and 'CNFC 10762' is also promising, based on the Euclidian distance $(\mathrm{D}=1.89)$. Another promising combination based on the Euclidean distance is 'BRS Ametista' (1) and 'CNFC 10764' (11) $(\mathrm{D}=1.87)$, and, by the Mahalanobis distance, 'BRS Esplendor' (3) and 'IAC Alvorada' (12) $\left(\mathrm{D}^{2}=1.87\right)$, highlighting the excellent agronomic performance of 'IAC Alvorada' (Table 4).

Genetics and Molecular Research 16 (1): gmr16019570 
Ward's clustering, which is based on both the Euclidian distance (Figure 1) and the Mahalanobis distance (Figure 2), classified the genotypes into three groups. Although the dissimilarity measures formed the same number of groups, there was a considerable difference in their compositions. However, there was some similarity, such as among 'BRS Estilo', 'CNFC 10762', and 'IAC Alvorada' (Group I, Mahalanobis distance and Group III, Euclidian distance); 'BRS Esteio' and 'CNFC 10762' (Group II, Mahalanobis distance and Group III, Euclidian distance); 'CNFC 10429', 'BRS Esplendor', and 'Pérola' (Group II, Mahalanobis distance and Group I, Euclidian distance); and 'IPR Tangará' and 'TAA Bola Cheia' (Group III, Mahalanobis distance and Group II, Euclidian distance). Similar results were obtained by Cargnelutti Filho et al. $(2008,2010)$ when assessing genetic divergence among common bean genotypes.

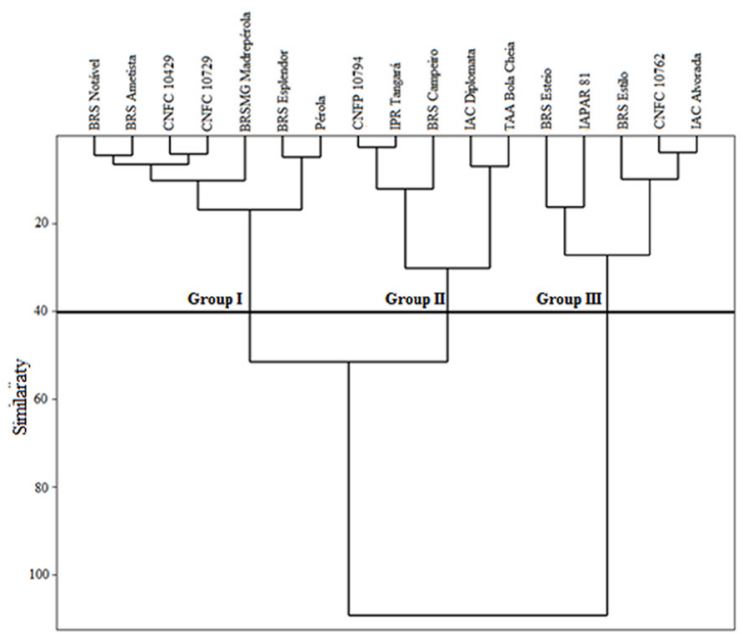

Figure 1. Dendrogram of genetic dissimilarity among 17 common bean genotypes obtained by Ward clustering method, using the Euclidean distance.

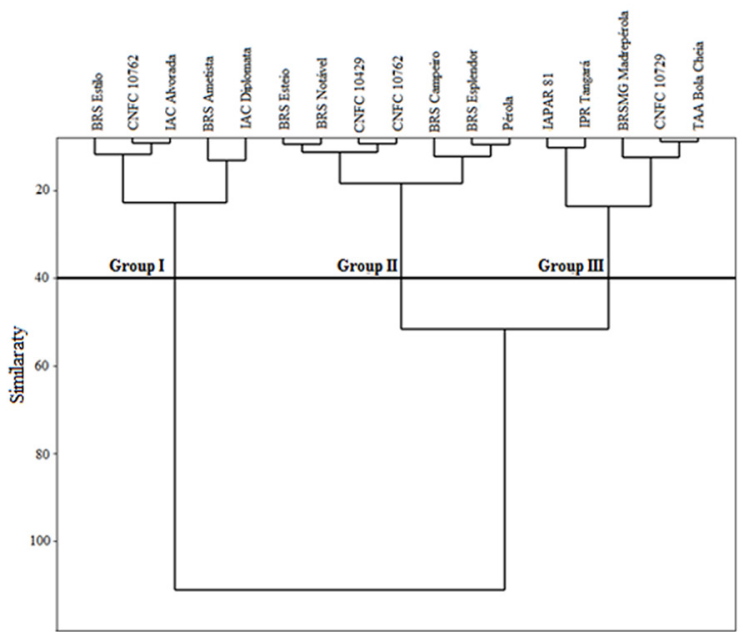

Figure 2. Dendrogram of genetic dissimilarity among 17 common bean genotypes obtained by Ward clustering method, using the Mahalanobis distance.

Genetics and Molecular Research 16 (1): gmr16019570 
The Euclidian distance should be preferentially used in trials that do not include repetition, because it is difficult to quantify environmental effects on genes. This technique is recommended for the evaluation of a large number of genotypes in germplasm banks, because the use of experimental design is unfeasible (Cruz et al., 2014). However, the Mahalanobis distance can only be estimated when the experimental design contemplates the use of experimental design, making it possible to quantify environmental effects (Cargnelutti Filho et al., 2010). Regardless of the dissimilarity measure used, grain yield was the trait that contributed most to genetic divergence among the genotypes (Table 6). Using Singh's (1981) criterion for ascertaining the relative contributions of different agronomic traits to genetic divergence in cowpea genotypes, Santos et al. (2014) found that differences between the traits depended on the type of measurement used. This may be because the Euclidean distance makes inferences about phenotypic dissimilarity, whereas the Mahalanobis distance measures genotypic dissimilarity (Cruz et al., 2014).

Table 6. Contribution of the traits days for emergence (DE), plant height (PH), number of ramifications per plant (NR), days for flowering (DF), days for maturation (DM), number of pods per plant (NPP), number of grains per pod (NGP), weight of hundred grains (WHG) and grain yield (YIE) for genetic divergence among the 16 soybean cultivars grown in Cerrado/Pantanal ecotone based on Singh (1981) criterion.

\begin{tabular}{l|c|c|c|c}
\hline \multirow{2}{*}{ Trait } & \multicolumn{2}{|c|}{ Euclidian distance } & \multicolumn{2}{c}{ Mahalanobis distance } \\
\cline { 2 - 5 } & Contribution & Contribution (\%) & Contribution & Contribution (\%) \\
\hline DE & 271.11 & 0.00 & 276.36 & 1.29 \\
\hline PH & $24,926.00$ & 0.04 & 889.60 & 4.16 \\
\hline NR & $5,262.22$ & 0.01 & $2,005.36$ & 9.38 \\
\hline DF & $1,719.11$ & 0.00 & $1,813.36$ & 8.49 \\
\hline NM & $2,275.11$ & 0.00 & $2,042.31$ & 0.75 \\
\hline NGP & 949.17 & 0.00 & 39.38 & 9.57 \\
\hline WHG & 114.09 & 0.00 & $3,160.29$ & 0.18 \\
\hline YIE & $1,856.54$ & 0.00 & $10,981.60$ & 14.79 \\
\hline
\end{tabular}

Traits that exhibit qualitative inheritance are good genetic markers, because they are little influenced by the environment and are probably controlled by a few genes (Ramalho et al., 1993). In contrast, evaluating morphological traits that are affected by environmental factors may result in significant deviations in the estimates (Barbosa Neto and Bered, 1998). Unsuitable traits for studies of genetic divergence include those that are relatively similar between individuals, those that are unstable in response to changes in environmental conditions, and those that are redundant because they are correlated with other traits (Cruz et al., 2014). Therefore, the genotypic correlation matrix should also be analyzed, in order to remove features that are redundant (Cruz et al., 2014).

\section{CONCLUSIONS}

The genotypes 'CNFC 10762', 'IAC Alvorada', and 'BRS Estilo' had the best performances in terms of grain yield, and grain yield was the most divergent trait among the genotypes. The genotypes were divided into three groups with different compositions by both dissimilarity measures, and hybrids with a large heterotic effect can be obtained from crosses between 'BRS Esplendor' and 'CNFC 10762', 'Ametista' and 'CNFC 10762', 'Ametista' and 'CNFC 10764', and 'BRS Esplendor' and 'IAC Alvorada'.

Genetics and Molecular Research 16 (1): gmr16019570 


\section{Conflicts of interest}

The authors declare no conflicts of interest.

\section{ACKNOWLEDGMENTS}

We thank Coordenação de Aperfeiçoamento de Pessoal de Nível Superior (CAPES) and Conselho Nacional de Desenvolvimento Científico e Tecnológico (CNPq) for financial support.

\section{REFERENCES}

Araújo RS, Rava CA, Stone LF and Zimmermann MJO (1996). A cultura do feijoeiro comum no Brasil. Associação Brasileira para Pesquisa da Potassa e do Fosfato (POTAFOS), Piracicaba.

Barbosa Neto IT and Bered EE (1998). Marcadores moleculares e diversidade genética no melhoramento de plantas. In: Marcadores moleculares em plantas (UFRGS, ed.). UFRGS, Porto Alegre, 29-41.

Benitez LC, Rodrigues ICS, Arge LWP, Ribeiro MV, et al. (2011). Análise multivariada da divergência genética de genótipos de arroz sob estresse salino durante a fase vegetativa. Rev. Cienc. Agron. 42: 409-416. http://dx.doi. org/10.1590/S1806-66902011000200021

Bertan I, Carvalho FIF, Oliveira AC, Marchioro VS, et al. (2003). Comparações entre medidas de dissimilaridade e estatísticas multivariadas como critérios no direcionamento de hibridações em aveia. Cienc. Rural 33: 657-662. http://dx.doi.org/10.1590/S0103-84782003000400011

Cargnelutti Filho A, Ribeiro ND, Reis RCP, Souza JR, et al. (2008). Comparação de métodos de agrupamento para o estudo da divergência genética em cultivares de feijão. Cienc. Rural 38: 2138-2145. http://dx.doi.org/10.1590/ $\underline{\text { S0103-84782008000800008 }}$

Cargnelutti Filho A, Ribeiro ND and Burin C (2010). Consistência do padrão de agrupamento de cultivares de feijão conforme medidas de dissimilaridade e métodos de agrupamento. Pesqui. Agropecu. Bras. 45: 236-243.

Coelho GMM, Coimbra JLM, Souza CA and Guidolim AF (2007). Diversidade genética em acessos de feijão (Phaseolus vulgaris L.). Cienc. Rural 37: 1241-1247. http://dx.doi.org/10.1590/S0103-84782007000500004

CONAB (2015). Companhia Nacional de Abastecimento. Acompanhamento da Safra Brasileira de Grãos. Nono Levantamento.

Correa AM and Gonçalves MC (2012). Divergência genética em genótipos de feijão comum cultivados em Mato Grosso do Sul. Rev. Ceres 59: 206-212. http://dx.doi.org/10.1590/S0034-737X2012000200009

Correa AM, Souza Lima AR, Braga DC, Ceccon G, et al. (2015). Agronomic performance and genetic variability among common bean genotypes in Savanna/Pantanal ecotone. J. Agron. 14: 175-179. http://dx.doi.org/10.3923/ ja.2015.175.179

Cruz CD (2013). GENES- a software package for analysis in experimental statistics and quantitative genetics. Acta Sci. Agron. 35: 271-276. http://dx.doi.org/10.4025/actasciagron.v35i3.21251

Cruz CD, Carneiro PCS and Regazzi AJ (2014). Modelos biométricos aplicados ao Melhoramento Genético Vol. 2, 3rd edn. Editora UFV, Viçosa, MG, Brazil.

EMBRAPA (2006). Sistema Brasileiro de classificação de solos. 2nd edn. Embrapa/CNPS, Rio de Janeiro, Brazil.

EMBRAPA (2012). Centro Nacional de Pesquisa de Arroz e Feijão. Informações Técnicas para o cultivo do feijoeiro comum na Região Central Brasileira 2012-2014. EMBRAPA Arroz e Feijão, Documento, Santo Antônio de Goiás.

Falconer DS (1981). Introduction to quantitative genetics 2nd edn. Longman, London.

Falconer DS and Mackay TF (1996). Introduction to quantitative genetics. 4th edn. Longman, London.

Gonçalves DL, Ambrozio VC, Barelli MAA, Neves LG, et al. (2014). Divergência genética de acessos tradicionais de feijoeiros através de características da semente. Biosci. J. 30: 1671-1681.

Lemos LB, Oliveira RS, Palomino EC and Silva TRB (2004). Características agronômicas e tecnológicas de genótipos de feijão do grupo comercial Carioca. Pesqui. Agropecu. Bras. 39: 319-326. http://dx.doi.org/10.1590/S0100204X2004000400004

Martins IS, Pires IE and Oliveira MC (2002). Divergência genética em progênies de uma população de Eucalyptus camaldulensis DEHNH. Floresta Ambient. 9: 81-89.

Montgomery DC and Peck EA (1981). Introduction to linear regression analysis. John Wiley, New York.

Ramalho MAP, Santos JB and Zimermmann MJO (1993). Genética quantitativa em plantas autógamas: aplicações ao

Genetics and Molecular Research 16 (1): gmr16019570 
melhoramento do feijoeiro. UFG, Goiânia.

Ribeiro ND, Domingues LS, Gruhn EM, Zemolin AEM, et al. (2014). Desempenho Agronômico e qualidade de cozimento de linhagens de feijão de grãos especiais. Rev. Ciênc. Agro. 45: 92-100.

Santos A, Correa AM, Melo CLP, Durante LG, et al. (2011). Desempenho agronômico de feijão comum cultivado no período da seca em Aquidauana-MS. Rev. Agra. 4: 33-42.

Santos JAS, Soares CMG, Corrêa AM, Teodoro PE, et al. (2014). Agronomic performance and genetic dissimilarity among cowpea (Vigna unguiculata (L.) Walp.) genotypes. Glob. Advan. Res. J. Agric. Sci. 3: 678-682.

Schiavo JA, Pereira MG, Miranda LPM, Dias Neto AH, et al. (2010). Caracterização e classificação de solos desenvolvidos de arenitos da formação Aquidauana-MS. Rev. Bras. Cienc. Solo 34: 881-889. http://dx.doi.org/10.1590/S0100$\underline{06832010000300029}$

Scott AJ and Knott MA (1974). A cluster analysis method for grouping means in the analysis of variance. Biometrics 30 : 507-512. http://dx.doi.org/10.2307/2529204

Singh D (1981). The relative importance of characters affecting genetics divergence. Indian J. Genet. Plant Breed. 41: 237-245.

Teixeira IR, Silva GC, Timossi PC and Silva AG (2011). Desempenho agronômico de cultivares de feijão comum consorciado com mamona. Rev. Caat. 24: 55-61.

Teodoro PE, Rigon JPG, Torres FE, Ribeiros LP, et al. (2015). Comparison of clustering methods for study of genetic dissimilarity in soybean genotypes. Afr. J. Agric. Res. 10: 1331-1337.

Vidigal MG, Vidigal PSF, Amaral ATJ and Braccini AL (1997). Divergência genética entre cultivares de mandioca por meio de estatística multivariada. Bragantia 56: 263-271. http://dx.doi.org/10.1590/S0006-87051997000200005

Ward J (1963). Hierarchical grouping to optimize an objective function. J. Am. Stat. Assoc. 58: 236-244. http://dx.doi.org $\underline{10.1080 / 01621459.1963 .10500845}$

Zimmermann MJ, Carneiro JE, Del Pedroso MJ, Costa JGC, et al. (1996). Melhoramento genético e cultivares. In: Cultura do Feijoeiro Comum no Brasil (Araujo RS, Rava CA, Stone LF and Zimmermann MJO, eds.). Associação Brasileira para Pesquisa da Potassa e do Fosfato (POTAFOS), Piracicaba, Brazil, 223-262.

Genetics and Molecular Research 16 (1): gmr16019570 